\title{
Emendation of the Genus Cytophaga and Transfer of Cytophaga agarovorans and Cytophaga salmonicolor to Marinilabilia gen. nov.: Phylogenetic Analysis of the Flavobacterium-Cytophaga Complex
}

\author{
YASUYOSHI NAKAGAWA* AND KAZUHIDE YAMASATO $\dagger$ \\ Institute of Applied Microbiology, The University of Tokyo, \\ Bunkyo-ku, Tokyo 113, Japan $\ddagger$
}

\begin{abstract}
A 16S rRNA sequence analysis revealed that the genera Cytophaga, Flavobacterium, and Flexibacter are all polyphyletic and should be redefined and reorganized. Cytophaga hutchinsonii, the type species of the genus Cytophaga, belongs to a lineage that also contains Cytophaga aurantiaca. The genus Cytophaga is emended so that it contains only these two species, which decompose distinctly crystalline cellulose. Cytophaga salmonicolor and Cytophaga agarovorans form a lineage which is intermediate between other aerobic species and anaerobic bacteroides. Phenotypically, these organisms are characterized by being facultative anaerobes, inhabiting marine environments, and containing menaquinone-7 and spermidine. We propose that $C$. salmonicolor and $C$. agarovorans should be transferred to the genus Marinilabilia gen. nov. as Marinilabilia salmonicolor comb. nov. and Marinilabilia agarovorans comb. nov., respectively.
\end{abstract}

The genus Cytophaga was first described for aerobic cellulose-degrading bacteria by Winogradsky (31). Subsequently, this taxon was expanded to include organisms which degrade other biomacromolecules, such as agar and/or chitin $(17,23$ 26). However, several taxonomic investigations $(3,4,8,14,21)$ revealed unreasonable overlapping of phenotypic and chemotaxonomic characteristics between members of the genera $C y$ tophaga and Flavobacterium, which formed a taxon that came to be called the Flavobacterium-Cytophaga complex. The genera Cytophaga and Flavobacterium, along with the genera Bacteroides and Flexibacter and other genera, constitute one phylum of bacteria (33) as determined by cataloging (16) and sequencing (31) of $16 \mathrm{~S}$ rRNA. Intra- and intergeneric relationships between members of the Flavobacterium-Cytophaga complex have gradually been elucidated by studying $16 \mathrm{~S}$ rRNA sequences $(6,12,13,29,34)$ and DNA-rRNA hybridization data $(1,19,20)$. These studies have revealed that phylogenetically the genera Cytophaga and Flavobacterium could be divided into several groups, some of which included both Cytophaga and Flavobacterium species and some of which were elevated to genus rank. Vandamme et al. (28) proposed the genus Chryseobacterium for the Flavobacterium gleum group, the genus Bergeyella for Weeksella zoohelcum, and the genus Empedobacter for Flavobacterium breve. However, many misclassified cytophagas and flavobacteria remain. In this paper, the basis of the results of a study on comparative analysis of 16S rRNA sequences and a phenotypic examination of 62 strains belonging to the Flavobacterium-Cytophaga complex and related genera, we propose that the genus Cytophaga should be emended and that Cytophaga salmonicolor and $C y$ tophaga agarovorans should be transferred to the genus Marinilabilia gen. nov. as Marinilabilia salmonicolor comb. nov. (the

\footnotetext{
* Corresponding author. Present address: Institute for Fermentation, Osaka, 17-85 Juso-honmachi 2-chome, Yodogawa-ku, Osaka 532, Japan. Phone: 81-6-300-6555. Fax: 81-6-300-6814.

$\uparrow$ Present address: Culture Collection Center, Tokyo University of Agriculture, 1-1, Sakuragaoka 1-chome, Setagaya-ku, Tokyo 156, Japan.

$\ddagger$ The present name of the former Institute of Applied Microbiology is Institute of Molecular and Cellular Biosciences.
}

type species) and Marinilabilia agarovorans comb. nov., respectively.

Most of the strains which we used are type strains; the only exceptions were Cytophaga sp. strain L-43-1-N and Flexibacter maritimus JCM 8137. Cytophaga sp. strain L-43-1-N and Flexibacter maritimus No. $449^{\mathrm{T}}$ ( $\mathrm{T}=$ type strain) were provided by H. Kojima (Japan Leather Research Institute, Tokyo, Japan) and H. Wakabayashi (The University of Tokyo, Tokyo, Japan), respectively. The other strains which we used were obtained from culture collections. The procedures used to determine the quinone systems and the sequences of $16 \mathrm{~S}$ rRNAs have been described previously (12). Our sequencing experiments generated a continuous stretch of sequence from position 100 to position 1375 (Escherichia coli numbering system). The $16 \mathrm{~S}$ rRNA sequences which we determined and other sequences were compared as follows. Sequences determined in this study and previous studies $(12,13)$ and obtained from previously published papers $(6,15,29,31,34)$ were aligned with the sequence of Cytophaga hutchinsonii DSM 1761, the type strain of the type species of the genus Cytophaga. Escherichia coli (2) was included as an outgroup. The software package Clustal V (9) was used to generate similarity values and evolutionary distances ( $K_{\text {nuc }}$ values) (11) and to reconstruct a phylogenetic tree by the neighbor-joining method (18) from the $K_{\text {nuc }}$ values. Positions at which the secondary structures varied in the strains (positions 179 to 220,447 to 487,837 to 849,991 to 1045 , and 1134 to 1140 ) were not included in the analysis. The total number of nucleotides compared was 835 after we eliminated all sites which were not determined in any sequence. The topology of the tree was evaluated by the bootstrap resampling method (5) with 1,000 replicates. If the confidence limit for a group as determined by the bootstrap resampling method was more than $95 \%$, the group was considered statistically significant (5).

The respiratory quinones identified in this study were menaquinone 6 (MK-6) and MK-7; MK-6 was found in Bergeyella zoohelcum NCTC $11660^{\mathrm{T}}$, Flavobacterium branchiophilum No. $270^{\mathrm{T}}$, and Flexibacter maritimus No. $449^{\mathrm{T}}$, and MK-7 was found in Flexibacter elegans IFO $15055^{\mathrm{T}}$, Flexibacter filiformis IFO $15056^{\mathrm{T}}$, and Flavobacterium yabuuchiae IFO $14975^{\mathrm{T}}$. The iso- 
TABLE 1. Characteristics of the genus Marinilabilia and allied aerobic and facultatively anaerobic genera ${ }^{a}$

\begin{tabular}{|c|c|c|c|c|c|c|}
\hline Genus & Habitat(s) & $\begin{array}{l}\text { Oxygen } \\
\text { requirement" }\end{array}$ & Pigmentation & $\begin{array}{c}\mathrm{G}+\mathrm{C} \text { content } \\
(\mathrm{mol} \%)\end{array}$ & Polyamine $^{c}$ & Quinone(s) \\
\hline Marinilabilia & Marine & $\mathrm{F}$ & + & $37-41$ & Spd & MK-7 \\
\hline Bergeyella & Parasitic, saprophytic & A & - & $35-37$ & $\mathrm{ND}^{d}$ & MK-6 \\
\hline Capnocytophaga & Parasitic & $\mathrm{F}$ & + & $33-41$ & ND & MK-6 \\
\hline Chryseobacterium & Parasitic, free living & A & + & $33-38$ & Hspd & MK-6 \\
\hline Cytophaga & Soil & A & + & $39-42$ & Hspd & MK-7 \\
\hline Empedobacter & Parasitic, free living & A & + & $31-33$ & Hspd & MK-6 \\
\hline Flavobacterium & Soil, freshwater & A & + & 32 & Hspd & MK-6 \\
\hline Flexibacter & Soil, freshwater & A & + & $29-48$ & Hspd & MK-6, MK-7 \\
\hline Ornithobacterium & Parasitic & F & - & $37-39$ & ND & MK-7 \\
\hline Microscilla & Marine & A & + & $32-44$ & ND & ND \\
\hline Riemerella & Parasitic & A & - & $29-35$ & ND & MK-7 \\
\hline Sphingobacterium & Parasitic, free living & A & + & $39-42$ & Hspd & MK-7 \\
\hline Weeksella & Parasitic, saprophytic & A & - & $35-38$ & ND & MK-6 \\
\hline
\end{tabular}

"Data from this study and references $7,10,12$ to $14,19,22,27$ to 29 , and 35 .

${ }^{b} \mathrm{~F}$, facultative anaerobes; A, strict aerobes.

' Spd, spermidine; Hspd, homospermidine.

${ }^{d} \mathrm{ND}$, not determined.

prenoid quinones of the members of the Flavobacterium-Cytophaga complex and related genera which are characterized by containing MK-6 and/or MK-7 are summarized in Table 1 . The strains of Bacteroides species are characterized by containing MK-6, MK-7, MK-9, MK-10, MK-11, MK-12, or MK-13, and Porphyromonas strains are characterized by containing MK-9 or MK-10 (35). The major isoprenoid quinones of Bacteroides splanchnicus and Rikenella microfusus are MK-9 and MK-8, respectively.

The reconstructed phylogenetic tree revealed the extreme heterogeneity of this group of bacteria (Fig. 1). The genera Cytophaga, Flavobacterium, and Flexibacter all are polyphyletic and should be redefined and divided into several genera based on phylogenetic relationships. The species assigned to each of these genera belong to several lineages which are only remotely related to each other at the genus level. Once discriminating phenotypic characteristics have been identified, these phylogenetic lineages should be reclassified in new or previously described genera.

The only species that was closely related to Cytophaga hutchinsonii, the type species of the genus Cytophaga, was Cytophaga aurantiaca (Fig. 1). Our bootstrap analysis resulted in a confidence value of $100 \%$ for the group containing these two species. The level of $16 \mathrm{~S}$ rRNA sequence similarity for these two species was $98.9 \%$, and the levels of $16 \mathrm{~S}$ rRNA sequence similarity between them and other members of the complex were less than $87.3 \%$ (Table 2 ). In addition to constituting an independent phylogenetic lineage, these two species have similar phenotypic characteristics; they both contain MK-7, inhabit terrestrial environments, and are able to degrade crystalline cellulose, which is the defining characteristic given in the original description of the genus (32). On the basis of the facts described above, the genus Cytophaga should be confined to these two species, which have the distinguishing phenotypic feature of the genus, the ability to degrade cellulose as Reichenbach (17) discerningly suggested.

Cytophaga salmonicolor, Cytophaga agarovorans, and Cytophaga fermentans are marine, facultatively anaerobic species that contain MK-7. They are also characterized by having spermidine as their major polyamine, in contrast to most other species belonging to the complex, which contain homospermidine (7). Phylogenetically, Cytophaga salmonicolor and Cytophaga agarovorans occupy an independent position in this group of bacteria (Fig. 1). They have exhibit a high level of $16 \mathrm{~S}$
rRNA sequence similarity with each other (98.9\%), but lower levels of similarity with Cytophaga fermentans (around 92\%) (Table 2). The grouping of Cytophaga salmonicolor and Cytophaga agarovorans is supported by a confidence value of $100 \%$.

On the basis of phylogenetic, chemotaxonomic, and physiological data, we propose that the genus Cytophaga should be emended and that Cytophaga salmonicolor and Cytophaga agarovorans should be transferred to the genus Marinilabilia gen. nov. as Marinilabilia salmonicolor (Veldkamp 1961) comb. nov. and Marinilabilia agarovorans (Reichenbach 1989) (Cytophaga salmonicolor var. agrovorans Veldkamp 1961) comb. nov., respectively, in order to partially solve the taxonomic confusion surrounding this group of bacteria. Characteristics of the genus Marinilabilia and allied bacteria are shown in Table 1.

Emended description of the genus Cytophaga Winogradsky $1929,577^{\mathrm{AL}}$, emend. Cells are short to moderately long flexible rods that are 0.3 to $0.5 \mu \mathrm{m}$ wide and 2 to $10 \mu \mathrm{m}$ long and have slightly tapered ends. Resting stages are absent. Motile by gliding. Gram negative. The cell mass is usually pigmented yellow to orange because of cell-bound carotenoids, flexirubin type pigments, or both. When covered with alkali (e.g., a $20 \%$ $\mathrm{KOH}$ solution [flexirubin reaction]), colonies may reversibly change color from yellow to purple- or red-brown. Oxidase positive and catalase negative. Strict aerobes. Chemoorganotrophs. Metabolism is respiratory. Organic acids may also be produced during growth. All strains decompose crystalline cellulose (filter paper). The optimum temperature is 20 to $30^{\circ} \mathrm{C}$. The optimum $\mathrm{pH}$ is around 7. Common in soil. The major polyamine is homospermidine. The quinone is MK-7. The $\mathrm{G}+\mathrm{C}$ content of the DNA is 39 to $42 \mathrm{~mol} \%$.

The type species is Cytophaga hutchinsonii. The other species in the genus is Cytophaga aurantiaca. These two species can be differentiated by the color of the cell mass, the flexirubin reaction, and the optimum temperature (17).

Description of Marinilabilia gen. nov. Marinilabilia (Ma.ri.ni. la'bi.lia. L. adj. marinus, marine, pertaining to the sea; L. adj. labilis, gliding; M. L. fem. n. Marinilabilia, marine gliding organisms). The description of the genus Marinilabilia gen. nov. below is taken from the data of Reichenbach (17) and Veldkamp (30) and our own data. Cells are short to very long flexible rods with rounded or slightly tapered ends and are 0.3 to $0.5 \mu \mathrm{m}$ wide and 2 to $50 \mu \mathrm{m}$ long. Resting stages are absent. Motile by gliding. Gram negative. The cell mass is pale yellow to salmon (usually pink to salmon). Chemoorganotroph. Me- 


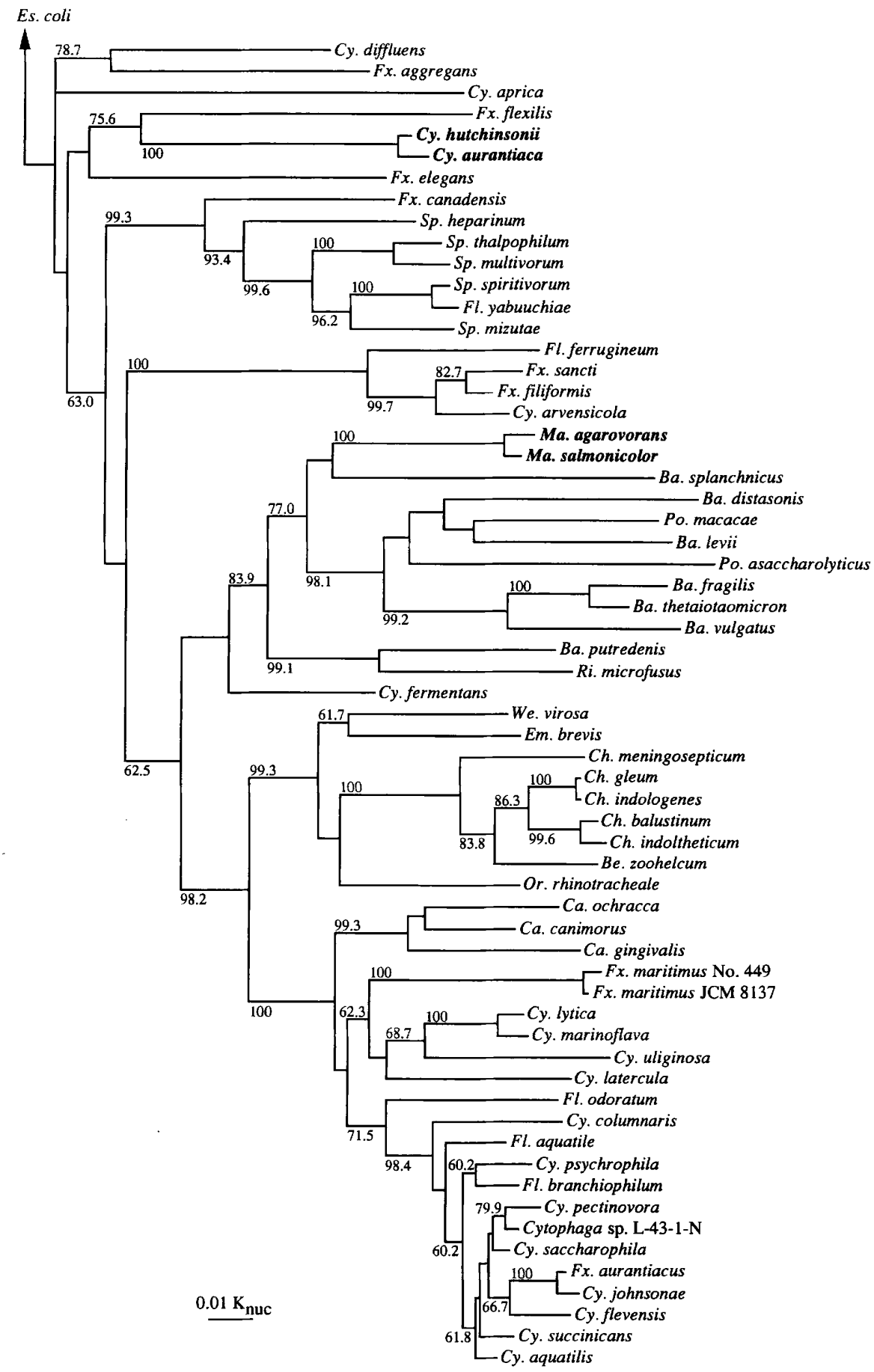

FIG. 1. Phylogenetic tree derived from 16S rRNA sequences for the members of the Flavobacterium-Cytophaga complex and related genera. All of the sequences except the Cytophaga sp. strain L-43-1-N and Flexibacter maritimus JCM 8137 sequences are sequences of type strains. Escherichia coli was used as the root organism. Scale bar $=0.01 K_{\text {nuc }}$ in nucleotide sequences. The lengths of the vertical lines are not significant. The numbers on the branches are the confidence limits (expressed as percentages) estimated by a bootstrap analysis of 1,000 replicates. Confidence limits less than $60 \%$ are not shown. Abbreviations: Es., Escherichia; Cy., Cytophaga; Fx., Flexibacter, Sp., Sphingobacterium; Fl. Flavobacterium; Ma., Marinilabilia; Ba., Bacteroides; Po., Porphyromonas; Ri., Rikenella; We., Weeksella; Em., Empedobacter; Ch., Chryseobacterium; Be., Bergeyella; Or., Ornithobacterium; Ca., Capnocytophaga.

tabolism is respiratory and fermentative. Catalase positive. All strains decompose several kinds of biomacromolecules. Marine organisms requiring elevated salt concentrations. The optimum temperature is 28 to $37^{\circ} \mathrm{C}$. The optimum $\mathrm{pH}$ is around 7. The major polyamine is spermidine. The quinone is MK-7. The $\mathrm{G}+\mathrm{C}$ content of the DNA is 37 to $41 \mathrm{~mol} \%$. The type species of the genus is Marinilabilia salmonicolor. The other species which belongs to the genus is Marinilabilia agarovorans.

The descriptions of Marinilabilia salmonicolor comb. nov. and Marinilabilia agarovorans comb. nov. are the same as those given by Reichenbach (17). These two species can be differentiated on the basis of the ability to degrade agar. 


\begin{tabular}{|c|c|c|}
\hline 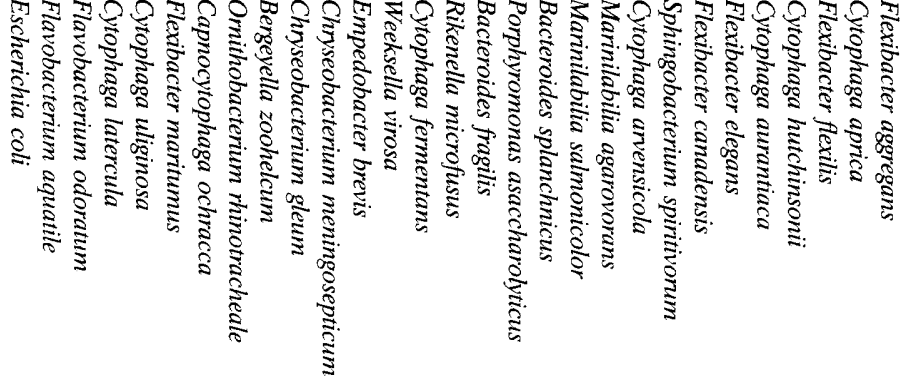 & 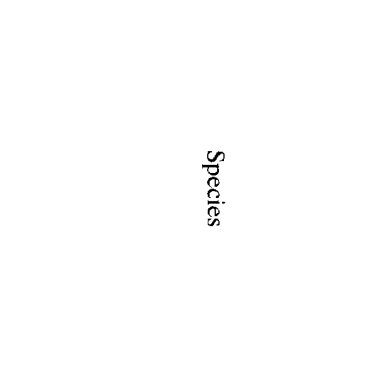 & \\
\hline 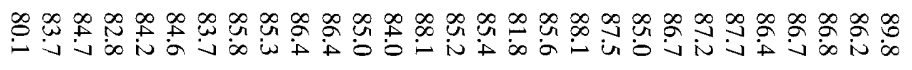 & Cytophaga diffluens & \\
\hline 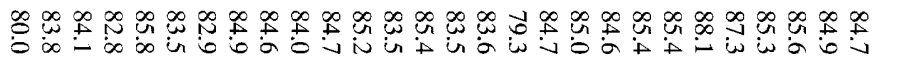 & Flexibacter aggregans & \\
\hline 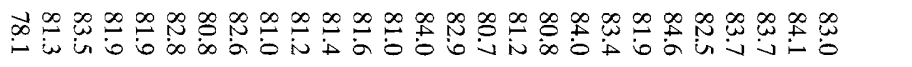 & Cytophaga aprica & \\
\hline 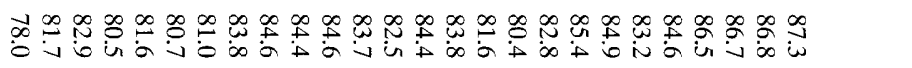 & Flexibacter flexilis & \\
\hline 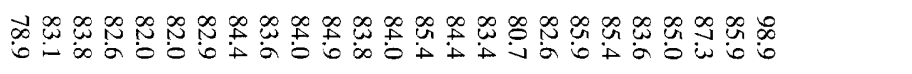 & Cytophaga hutchinsonii & \\
\hline 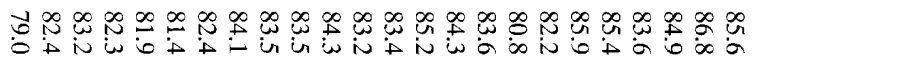 & Cytophaga aurantiaca & \\
\hline 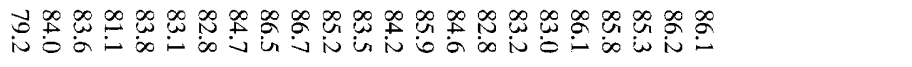 & Flexibacter elegans & \\
\hline 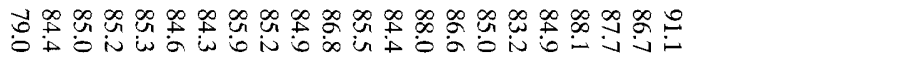 & Flexibacter canadensis & \\
\hline 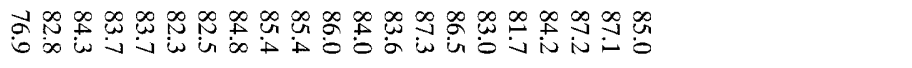 & Sphingobacterium spiritivorum & \\
\hline 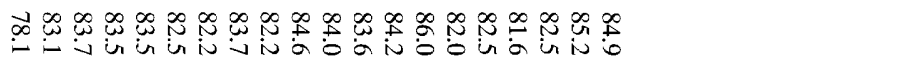 & Cytophaga arvensicola & \\
\hline 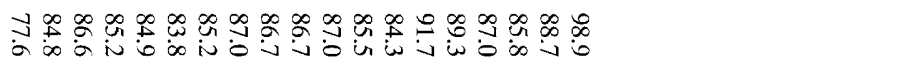 & Marinilabilia agarovorans & \\
\hline 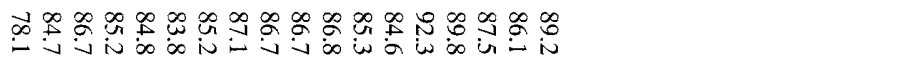 & Marinilabilia salmonicolor & \\
\hline 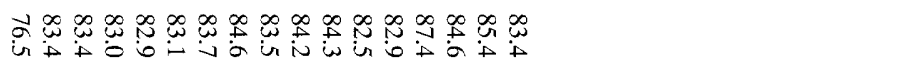 & Bacteroides splanchnicus & \\
\hline 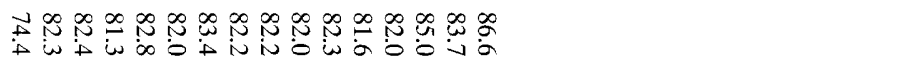 & Porphyromonas asaccharolyticus & 29 \\
\hline 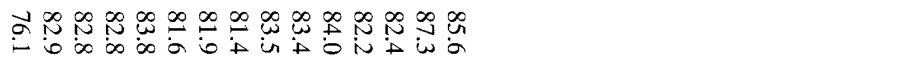 & Bacteroides fragilis & : \\
\hline 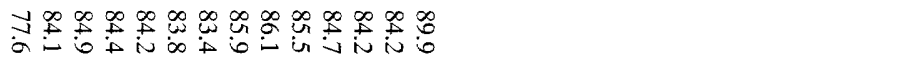 & Rikenella microfusus & $\stackrel{2}{\approx}$ \\
\hline 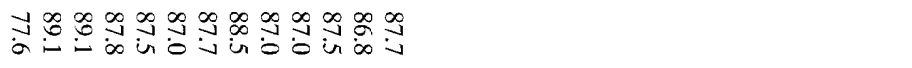 & Cytophaga fermentans & \\
\hline 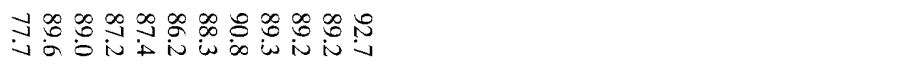 & Weeksella virosa & \\
\hline 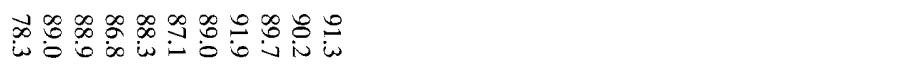 & Empedobacter brevis & \\
\hline 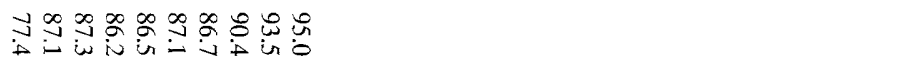 & Chryseobacterium meningosepticum & \\
\hline 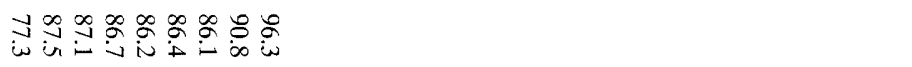 & Chryseobacterium gleum & \\
\hline 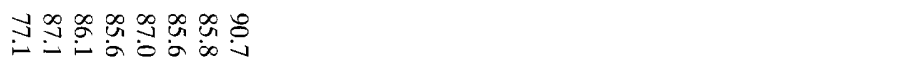 & Bergeyella zoohelcum & \\
\hline 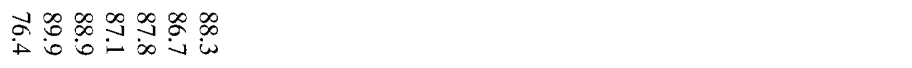 & Ornithobacterium rhinotracheale & \\
\hline 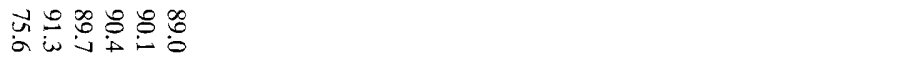 & Capnocytophaga ochracca & \\
\hline 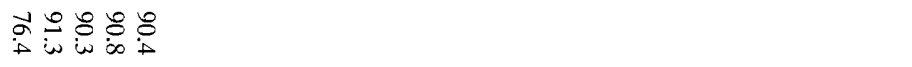 & Flexibacter maritimus & \\
\hline 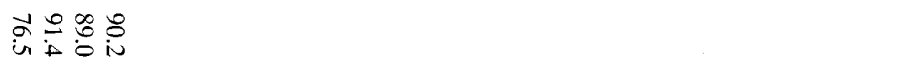 & Cytophaga uliginosa & \\
\hline 웡요 & Cytophaga latercula & \\
\hline 蓆 & Flavobacterium odoratum & \\
\hline$\underset{\infty}{\alpha}$ & Flavobacterium aquatile & \\
\hline
\end{tabular}


Nucleotide sequence accession numbers. The $16 \mathrm{~S}$ rRNA sequence data which we determined have been deposited in the DDBJ, EMBL, GSDB, and NCBI nucleotide databases under the following accession numbers: D14016 for Chryseobacterium balustinum IFO $15053^{\mathrm{T}}$, D14018 for Chryseobacterium meningosepticum IFO $12535^{\mathrm{T}}$, D14022 for Empedobacter brevis IAM $14197^{\mathrm{T}}$, D14017 for Flavobacterium branchiophilum No. $270^{\mathrm{T}}$, D14019 for Flavobacterium odoratum JCM $7458^{\mathrm{T}}$, D14021 for Flavobacterium yabuuchiae IFO $14975^{\mathrm{T}}$, (Flavobacterium yabuuchiae is now recognized as a junior subjective synonym of Sphingobacterium spiritivorum [27]), D14023 for Flexibacter maritimus No. $449^{\mathrm{T}}$, D14026 for Sphingobacterium spiritivorum JCM $1277^{\mathrm{T}}$, D14024 for Sphingobacterium mizutae IFO $14946^{\mathrm{T}}$, D14025 for Sphingobacterium multivorum IFO $14947^{\mathrm{T}}$, and D14020 for Sphingobacterium thalpophilum IFO $14963^{\mathrm{T}}$.

We thank the American Type Culture Collection (Rockville, Md.), the Deutsche Sammlung von Mikroorganismen und Zellkulturen GmbH (Braunschweig, Germany), the Institute of Applied Microbiology, the University of Tokyo (Tokyo, Japan), the Institute for Fermentation, Osaka (Osaka, Japan), the Japan Collection of Microorganisms (Wako, Japan), the National Collection of Industrial and Marine Bacteria, Ltd. (Aberdeen, United Kingdom), and the National Collection of Type Cultures, Public Health Laboratory Service (London, United Kingdom) for kindly supplying bacterial cultures. We are grateful to $T$. Sakane (Institute for Fermentation, Osaka) for offering every convenience and A. Nakagiri (Institute for Fermentation, Osaka) for suggesting the name Marinilabilia.

This work was supported in part by Grant-in-Aid for Co-operative Research 03304017 from the Ministry of Education, Science and Culture of Japan.

\section{REFERENCES}

1. Bauwens, M., and J. De Ley. 1981. Improvements in the taxonomy of Flavobacterium by DNA:rRNA hybridizations, p. 27-31. In H. Reichenbach and O. B. Weeks (ed.), The Flavobacterium-Cytophaga group. Verlag Chemie, Weinheim, Germany.

2. Brosius, J., M. L. Palmer, P. J. Kennedy, and H. F. Noller. 1978. Complete nucleotide sequence of a $16 \mathrm{~S}$ ribosomal RNA gene from Escherichia coli. Proc. Natl. Acad. Sci. USA 75:4801-4805.

3. Callies, E., and W. Mannheim. 1978. Classification of the FlavobacteriumCytophaga complex on the basis of respiratory quinones and fumarate respiration. Int. J. Syst. Bacteriol. 28:14-19.

4. Christensen, P. J. 1977. The history, biology, and taxonomy of the Cytophaga group. Can. J. Microbiol. 23:1599-1653.

5. Felsenstein, J. 1985. Confidence limits on phylogenies: an approach using the bootstrap. Evolution 39:783-791.

6. Gherna, R., and C. R. Woese. 1992. A partial phylogenetic analysis of the "flavobacter-bacteroides" phylum: basis for taxonomic restructuring. Syst. Appl. Microbiol. 15:513-521.

7. Hamana, K., Y. Nakagawa, and K. Yamasato. 1995. Chemotaxonomic significance of polyamine distribution patterns in the Flavobacterium-Cytophaga complex and the related genera. Microbios 81:135-145.

8. Hayes, P. R. 1977. A taxonomic study of flavobacteria and related gram negative yellow pigmented rods. J. Appl. Bacteriol. 43:345-367.

9. Higgins, D. G., A. J. Bleasby, and R. Fuchs. 1992. CLUSTAL V: improved software for multiple sequence alignment. Comput. Appl. Biosci. 8:189-191.

10. Holt, J. G., N. R. Krieg, P. H. A. Sneath, J. T. Staley, and S. T. Williams (ed.). 1994. Bergey's manual of determinative bacteriology, 9th ed. Williams \& Wilkins Co., Baltimore.

11. Kimura, M. 1980. A simple method for estimating evolutionary rates of base substitutions through comparative studies of nucleotide sequences. J. Mol. Evol. 16:111-120.

12. Nakagawa, Y., and K. Yamasato. 1993. Phylogenetic diversity of the genus Cytophaga revealed by $16 \mathrm{~S}$ rRNA sequencing and menaquinone analysis. J. Gen. Microbiol. 139:1155-1161.
13. Nakagawa, Y., and K. Yamasato. 1993. The molecular systematics of Cytophaga species based on the $16 \mathrm{~S}$ rRNA sequences, p. 163-170. In P. J. Jooste (ed.), Advances in the taxonomy and significance of Flavobacterium, Cytophaga and related bacteria. University Press, University of the Orange Free State, Bloemfontein, South Africa.

14. Oyaizu, H., and K. Komagata. 1981. Chemotaxonomic and phenotypic characterization of the strains of species in the Flavobacterium-Cytophaga complex. J. Gen. Appl. Microbiol. 27:57-107.

15. Paster, B. J., F. E. Dewhirst, I. Olsen, and G. J. Fraser. 1994. Phylogeny of Bacteroides, Prevotella, and Porphyromonas spp. and related genera. J. Bacteriol. 176:725-732.

16. Paster, B. J., W. Ludwig, W. G. Weisburg, E. Stackebrandt, R. B. Hespell, C. M. Hahn, H. Reichenbach, K. O. Stetter, and C. R. Woese. 1985. A phylogenetic grouping of the bacteroides, cytophagas, and certain flavobacteria. Syst. Appl. Microbiol. 6:34-42.

17. Reichenbach, H. 1989. Genus 1. Cytophaga, p. 2015-2050. In J. T. Staley, M. P. Bryant, N. Pfennig, and J. G. Holt (ed.), Bergey's manual of systematic bacteriology, vol. 3. The Williams \& Wilkins Co., Baltimore.

18. Saitou, N., and M. Nei. 1987. The neighbor-joining method: a new method for reconstructing phylogenetic trees. Mol. Biol. Evol. 4:406-425.

19. Segers, P., W. Mannheim, M. Vancanneyt, K. De Brandt, K.-H. Hinz, K. Kersters, and P. Vandamme. 1993. Riemerella anatipestifer gen. nov., comb. nov., the causative agent of septicemia anserum exsudativa, and its phylogenetic affiliation within the Flavobacterium-Cytophaga rRNA homology group. Int. J. Syst. Bacteriol. 43:768-776.

20. Segers, P., P. Vandamme, P. L. Steyn, W. Mannheim, H. Willekens, M. Bauwens, J. De Ley, and K. Kersters. 1993. Phylogenetic studies of Flavobacterium and related organisms by DNA-rRNA hybridizations, p. 129-136. In P. J. Jooste (ed.), Advances in the taxonomy and significance of Flavobacterium, Cytophaga and related bacteria. University Press, University of the Orange Free State, Bloemfontein, South Africa.

21. Shewan, J. M., and T. A. McMeekin. 1983. Taxonomy (and ecology) of Flavobacterium and related genera. Annu. Rev. Microbiol, 37:233-252.

22. Staley, J. T., M. P. Bryant, N. Pfennig, and J. G. Holt (ed.). 1989. Bergey's manual of systematic bacteriology, vol. 3. The Williams \& Wilkins Co., Baltimore.

23. Stanier, R. Y. 1940. Studies on the cytophagas. J. Bacteriol. 40:619-635.

24. Stanier, R. Y. 1941. Studies on marine agar-digesting bacteria. J. Bacteriol. 42:527-559.

25. Stanier, R. Y. 1942. The Cytophaga group: a contribution to the biology of myxobacteria. Bacteriol. Rev. 6:143-196.

26. Stanier, R. Y. 1947. Studies on nonfruiting myxobacteria. I. Cytophaga johnsonae n. sp., a chitin-decomposing myxobacterium. J. Bacteriol. 53:297315.

27. Takeuchi, M., and A. Yokota. 1992. Proposals of Sphingobacterium faecium sp. nov., Sphingobacterium piscium sp. nov., Sphingobacterium heparinum comb. nov., Sphingobacterium thalpophilum comb. nov. and two genospecies of the genus Sphingobacterium, and synonymy of Flavobacterium yabuuchiae and Sphingobacterium spiritivorum. J. Gen. Appl. Microbiol. 38:465-482.

28. Vandamme, P., J.-F. Bernardet, P. Segers, K. Kersters, and B. Holmes. 1994. New perspectives in the classification of the flavobacteria: description of Chryseobacterium gen. nov., Bergeyella gen. nov., and Empedobacter nom. rev. Int. J. Syst. Bacteriol. 44:827-831.

29. Vandamme, P., P. Segers, M. Vancanneyt, K. van Hove, R. Mutters, J. Hommez, F. Dewhirst, B. Paster, K. Kersters, E. Falsen, L. A. Devriese, M. Bisgaard, K.-H. Hinz, and W. Mannheim. 1994. Omithobacterium rhinotracheale gen. nov., sp. nov., isolated from the avian respiratory tract. Int. J. Syst. Bacteriol. 44:24-37.

30. Veldkamp, H. 1961. A study of two marine agar-decomposing, facultatively anaerobic myxobacteria. J. Gen. Microbiol. 26:331-342.

31. Weisburg, W. G., Y. Oyaizu, H. Oyaizu, and C. R. Woese. 1985. Natural relationship between bacteroides and flavobacteria. J. Bacteriol. 164:230236.

32. Winogradsky, S. 1929. Études sur la microbiologie du sol. Sur la dégradation de la cellulose dans le sol. Ann. Inst. Pasteur (Paris) 43:549-633.

33. Woese, C. R. 1987. Bacterial evolution. Microbiol. Rev. 51:221-271.

34. Woese, C. R., D. Yang, L. Mandelco, and K. O. Stetter. 1990. The flexibacterflavobacter connection. Syst. Appl. Microbiol. 13:161-165.

35. Yokota, A., M. Akagawa-Matsushita, A. Hiraishi, Y. Katayama, T. Urakami, and K. Yamasato. 1992. Distribution of quinone systems in microorganisms: gram-negative eubacteria. Bull. Jpn. Fed. Culture Collections 8:136-171. 